(C) 2014

Ситар О. В., кандидат біологічних наук

Навчально-науковий центр «Інститут біології», Київський національний університет імені Тараса Шевченка

Новицька Н. В., кандидат сільськогосподарських наук

Національний університет біоресурсів і природокористування України

\title{
ВМІСТ БІОЛОГІЧНО АКТИВНИХ РЕЧОВИН ФЕНОЛЬНОЇ ПРИРОДИ У НАСІННІ СӦ̈ (GLYCINE MAX (L.) MERR.) ЗА ДIÏ НЕIОННИХ КОЛОЇДНИХ РОЗЧИНІВ НАНОЧАСТОК МЕТАЛІВ
}

\section{Рецензент - кандидат сільськгосподарпських наук В. П. Кротінов}

\begin{abstract}
Висвітлено результати досліджень щуодо впливу передпосівної обробки насіння сої розчинами наночасток металів для регуляиї його біохімічного складу як джерела фармакологічно важливих сполук фенольної природи. Встановлено позитивний вплив обробки насіння сої неіонними колоїдними розчинами наночасток на основі срібла, молібдену, марганцюю та заліза для зростання вмісту лейкоанточіанів, ізофлавонів та поліфенолів у насінні сої. Зокрема, передпосівна обробка неіонними колоїдними розчинами наночасток металів на основі срібла, молібдену, марганцүю та заліза сприяла зростанню вмісту лейкоантоціанів, вміст ізофлавонів збільшився у середньому на $30 \%$ відносно контролю.
\end{abstract}

Ключові слова: соя, наночастки металів, лейкоантоиіани, ізофлавони, таніни.

Постановка проблеми. Питання раціонального використання мінеральних добрив у процесі вирощування сільськогосподарських культур на сьогодні є актуальним для збереження сталості навколишнього середовища та отримання високоякісної продукції рослинництва. Перспективним i багатообіцяючим підходом до вирішення проблеми екологічно збалансованого використання мінеральних добрив для харчових рослин є біофортифікація, що передбачає спрямоване створення харчових рослин, здатних самостійно накопичувати підвищені рівні вітамінів, мінералів, інших цільових сполук, i, водночас, міститимуть понижені кількості антинутрієнтів, токсинів й інших небажаних речовин [1]. Особливе місце у біофортифікаційних технологіях відводиться добривам, що містять цільові метали, зокрема мікроелементам.

Істотним у механізмах дії всіх мікроелементів $\epsilon$ їх здатність утворювати комплексні сполуки 3 різними органічними речовинами, у тому числі 3 білками, і в переважній більшості активізувати певні ферментативні системи. Це здійснюється різними шляхами - безпосередньою участю в складі молекул ферментів або їх активацією. Проте використання солей металів і їхніх хелатних з'єднань обмежене, з одного боку, існуванням гранично допустимої дози для рослин, а 3 іншого, - небезпекою забруднення навколишнього середовища іонами металів. Наприклад, біофортифікація цинковмісними добривами $\left(\mathrm{ZnSO}_{4}\right)$ може підвищити врожайність рослин на грунтах, що характеризуються дефіцитом цього елементу, а також збільшити концентрацію цинку в їстівних частинах рослин. 3 іншого боку, двохвалентне залізо (у формі $\mathrm{FeSO}_{4}$ ) у грунті швидко переходить у тривалентне, тому внесення залізовмісних добрив не спричиняє суттєвого підвищення вмісту заліза в рослинах. Значна кількість заліза, внесена в грунт, може пригнічувати ріст рослин і негативно впливати на грунтові мікробіоценози. У зв'язку з цим виникає необхідність не тільки заміни солей металів такою формою добрив, яка буде менше забруднювати навколишнє середовище і забезпечить мінімальні вимоги до концентрації, що використовується для обробки рослин і насіння, а також дасть можливість програмувати динаміку накопичення в рослинах біологічно активних сполук та сприяти розвитку біомаси рослини. До таких форм відносяться продукти нанотехнологій - наночастки металів. Вони, володіючи унікальними властивостями, можуть використовуватися як біопрепарати нового покоління, крім того вони економічно вигідні й впливають на підвищення продуктивності сільськогосподарських рослин і тварин. Відмінною особливістю наночасток металів $€$ їх мала токсичність у порівнянні з солями металів і здатність за досить малих доз активізувати фізіологічні й біохімічні процеси.

Аналіз основних досліджень і публікацій, у яких започатковано розв'язання проблеми. Висока ефективність наночасток металів в якості стимуляторів росту показана на розвитку вегета- 


\section{СІЛЬСЬКЕ ГОСПОДАРСТВО. РОСЛИННИЦТВО}

тивної маси та формуванні продуктивності сільськогосподарських рослин [22]. Однак у комплексі біофортифікаційних заходів залишається практично недослідженим ефективність технологій використання наночасток металів у вирощуванні сої, однієї з найпоширеніших зернобобових і найбільш біофортифікованої селекційним шляхом культури на нашій планеті [7]. Як найважливіша культура 3 виробництва білка соя $\epsilon$ також джерелом біологічно активних речовин фенольної природи, що широко використовуються в фармацевтичній і харчовій промисловості [25].

Ізофлавони - група природних гетероциклічних сполук фенольної природи - зустрічається, головним чином, у рослинах сої (Glycine $\max$ (L.) Merr.). Основними ізофлавонами сої $€$ геністеін і даідзеін та їх глюкозиди - геністин і даідзин (рис. 1) [10]. Ці природні сполуки проявляють яскраві естрогенні, антифунгіцидні, антипухлинні й антимутагенні властивості [11, 15, 18]. Низька частота деяких захворювань, яка спостерігається в азіатських країнах, пояснюється споживанням значної кількості сої та продуктів іiі переробки. Середнє споживання ізофлавонів сої в цих країнах становить 40-80 мг на добу $[14,16]$. Соєві продукти пропонуються для забезпечення захисної дії в разі серцево-судинних захворювань, захворюванні шлунка, печінки, сечового міхура, передміхурової залози, шкіри та шлунка, попередження розвитку ракових пухлин $[4,14]$.

Експерименти на тваринах і спостереження на людині показали, що соєвий білок проявляє гіпохолестеринемічну та антиатерогенні властивості. Зазначається, що соєвий білок, порівняно 3 білками тваринного походження, може значно зменшити концентрацію загального холестерину в сироватці крові, ліпопротеїнів низької щільності (ЛПНЩ), холестерину і тригліцеридів [5, 17]. Дослідження на приматах довели, що соєвий білок може проявляти свої антиатерогенні ефекти через зв'язані з ним ізофлавони [24]. Соєві ізофлавони також володіють антиоксидантними властивостями, які можуть захищати ЛПНЩ від окислення [6].

Епідеміологічні дослідження свідчать, що жінки, які споживають чимало соєвих продуктів, мають більш низькі показники розвитку остеопорозу [4]. У зв'язку з наявністю в ізофлавонів низької естрогенної активності, вживання соєвих продуктів було запропоновано як альтернатива гормональної терапії у жінок у постменопаузі [23]. Враховуючи тісний зв'язок між харчуванням i розвитком захворювань, потенційні наслідки вживання біологічно активних сполук, таких як фітоестрогени, вимагають глибшого вивчення. Це особливо характерно для все більш широкого використання соєвих продуктів у харчуванні людей.<smiles>O=c1c(-c2ccc(O)cc2)coc2cc(O)cc(O)c12</smiles><smiles>O=c1c(-c2ccc(O)cc2)coc2cc(O)ccc12</smiles><smiles>O=c1c(-c2ccc(O)cc2)coc2cc(OC(F)(F)F)cc(O)c12</smiles>

Геністин<smiles></smiles>

Даідзин

Рис. 1. Хімічна структура ізофлавонових агліконів та їх глюкозидів 


\section{СІЛЬСЬКЕ ГОСПОДАРСТВО. РОСЛИННИЦТВО}

Накопичення ізофлавонів у зерні сої залежить від генетичних особливостей сорту й умов вирощування. Так, коливання ізофлавонів у зерні 210 сортів сої, вирощених у Південній Дакоті, становило від 1161 до 2743 мкгхг ${ }^{-1}$, а їх вміст у зерні сої сорту Vinton 81, що вирощувався упродовж декількох років в одній місцевості, коливався в межах від 1176 до 3309 мкг $\times \Gamma^{-1}$, в той час як коливання за один рік становили 1176 до 1749 мкг $\times \Gamma^{-1}$ [9]. Тобто, кліматичні умови року впливали на накопичення ізофлавонів більше, ніж умови місцевості. Китамура зі співавт. [9] та Цукамото зі співавт. [21] показали, що концентрація ізофлавонів у насінні сої, вирощеної за умов дії високої температури була значно нижчою, ніж у насінні рослин, що піддавалися впливу низької температури.

У процесі вивчені біохімічного складу фенольних сполук насіння сої, отриманого з рослин, оброблених неіонними частками нанометалів, основна увага приділялася визначенню трансформацій специфічної, фармакологічно важливої групи речовин - ізофлавонів.

Мета: дослідити вплив наночасток металів на біохімічні властивості насіння сої як джерела фармакологічно важливих сполук фенольної природи.

Завдання: 1. Провести позакореневі підживлення посівів сої сорту Аннушка у фазу бутонізації та цвітіння однокомпонентними неіонними колоїдними препаратами наночастинок металів: 1. Розчин Fe $\left(10^{-9}\right)$, 2. Розчин $\mathrm{Zn}\left(10^{-9}\right)$, 3. Розчин $\mathrm{Cu}\left(10^{-9}\right)$, 4. Розчин Mn $\left(10^{-9}\right), 5$. Розчин Mo $\left(10^{-9}\right)$, 6. Розчин Со $\left(10^{-9}\right), 7$. Розчин $\mathrm{Ag}\left(10^{-9}\right)$.

2. Визначити в зерні сої вміст фармакологічно важливих груп речовин - ізофлавонів - залежно від застосування неіонних колоїдних розчинів наночасток металів ( $\mathrm{Fe}, \mathrm{Mn}, \mathrm{Mo}, \mathrm{Co}, \mathrm{Cu}, \mathrm{Zn}, \mathrm{Ag})$.

Матеріали і методи досліджень. Польові дослідження з вивчення впливу колоїдного розчину наночасток металів на формування врожаю сої проводили на полях кафедри рослинництва у ВП НУБіП України «Агрономічна дослідна станція». Агротехніка у досліді - загальноприйнята для північного Лісостепу.

Об'єкт досліджень - рослини сої (Glycine max (L.) Merr.) сорту вітчизняної селекції Аннушка (ультраранній).

Для 3'ясування параметрів якості насіння сої залежно від наночасток металів проводили два позакореневі підживлення посівів сої у фазу бутонізації та цвітіння однокомпонентними неіонними колоїдними препаратами наночастинок металів: 1. Розчин Fe (10-9), 2. Розчин Zn (10-9),
3. Розчин $\mathrm{Cu}$ (10-9), 4. Розчин $\mathrm{Mn}$ (10-9), 5. Розчин Мо (10-9), 6. Розчин Со (10-9), 7. Розчин Ag (10-9). Колоїдні розчини наночасток металів (109) отримані диспергуванням гранул заліза, міді, кобальту, молібдену, марганцю, цинку і срібла імпульсами електричного струму 3 амплітудою 100-2000 А у воді.

Неіонні колоїдні розчини наночасток металів (Fe, $\mathrm{Mn}, \mathrm{Mo}, \mathrm{Co}, \mathrm{Cu}, \mathrm{Zn}, \mathrm{Ag}$ ) для позакореневого підживлення рослин сої застосовували з нормою витати 1 л препарату на 100-300 л води (робочий розчин) і на 1 га. Контрольні варіанти насіння висівали сухим та замочували за добу до сівби у дистильованій воді.

Вміст загальних фенолів визначався за допомогою реактиву Фоліна [19]. Вміст загальних танінів визначали за допомогою реактиву Фоліна та полівінілполіпіролідону за модифікованою нами методикою Хагеман і Бултер (1978) [20]. Вміст проантоціанідинів аналізувався за допомогою реакції з бутанол- $\mathrm{HCl}$ [8].

Визначення флавоноїдів проводилося за методикою Маркам [12]. Отримані дані обраховували статистично за допомогою програми Microsoft Excel.

Повторність усіх дослідів була трикратна; вірогідність різниці між середніми арифметичними значеннями показників встановлювали за критерієм Стьюдента. Відмінності вважали суттєвими в разі значення $\mathrm{P} \leq 0,05$ [2].

Результати досліджень. У процесі вивчення дії нанопрепаратів на накопичення фенольних сполук у зерні сої було встановлено, що у варіантах із використанням препаратів на основі молібдену, марганцю, міді та заліза спостерігалося достовірне підвищення загального вмісту поліфенолів (рис. 2).

Незначні коливання у варіантах із використанням нанопрепаратів на основі срібла, кобальту, міді та цинку знаходилися в межах похибки досліду.

Достовірне підвищення вмісту танінів у зернівках сої спостерігалося лише у варіантах із використанням молібдену та цинку (рис. 3).

Слід відмітити, що сумарний вміст лейкоантоціанів достовірно збільшувався в усіх варіантах із використанням нанопрепаратів (рис. 4).

Результати аналізів вмісту ізофлавонів у зерні сої показали, що у варіантах з обробкою рослин розчинами нанопрепаратів на основі срібла, молібдену, марганцю та заліза спостерігалися достовірні зміни кількісного складу.

Так, їх вміст, відносно контролю, збільшився у середньому на $30 \%$. 


\section{СІЛЬСЬКЕ ГОСПОДАРСТВО. РОСЛИННИЦТВО}

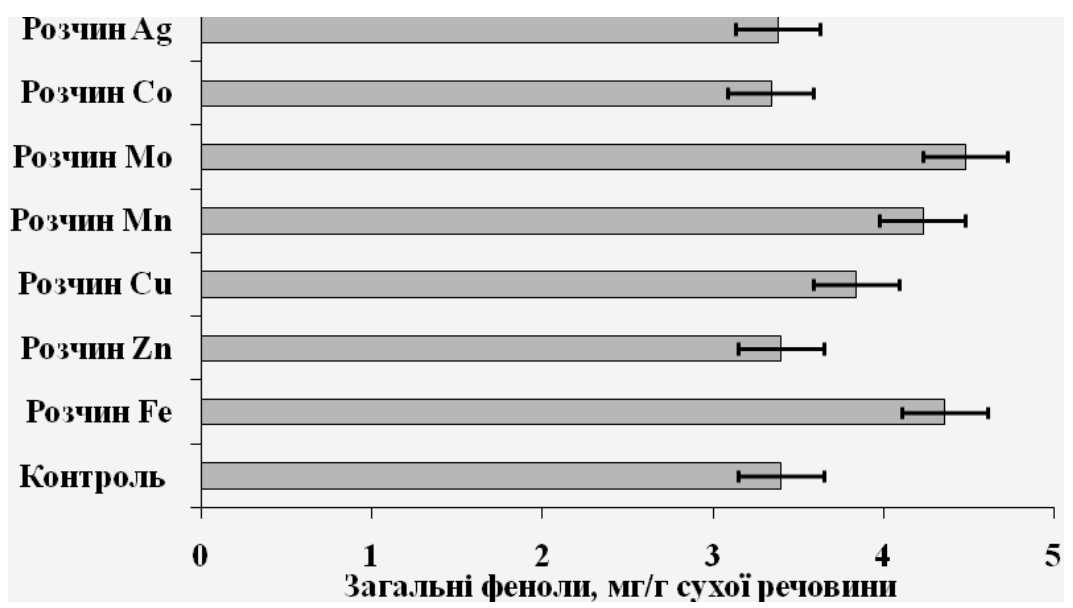

Рис. 2. Вміст суми фенольних сполук у зерні сої за передпосівної обробки нанопрепаратами, у перерахунку на галову кислоту

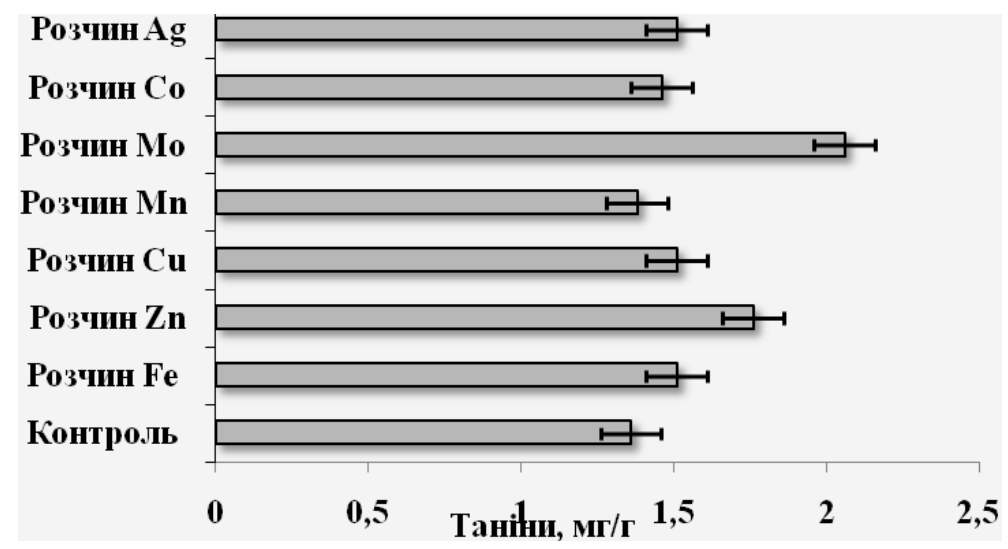

Рис. 3. Вміст танінів у зерні сої за передпосівної обробки нанопрепаратами, у перерахунку на катехін

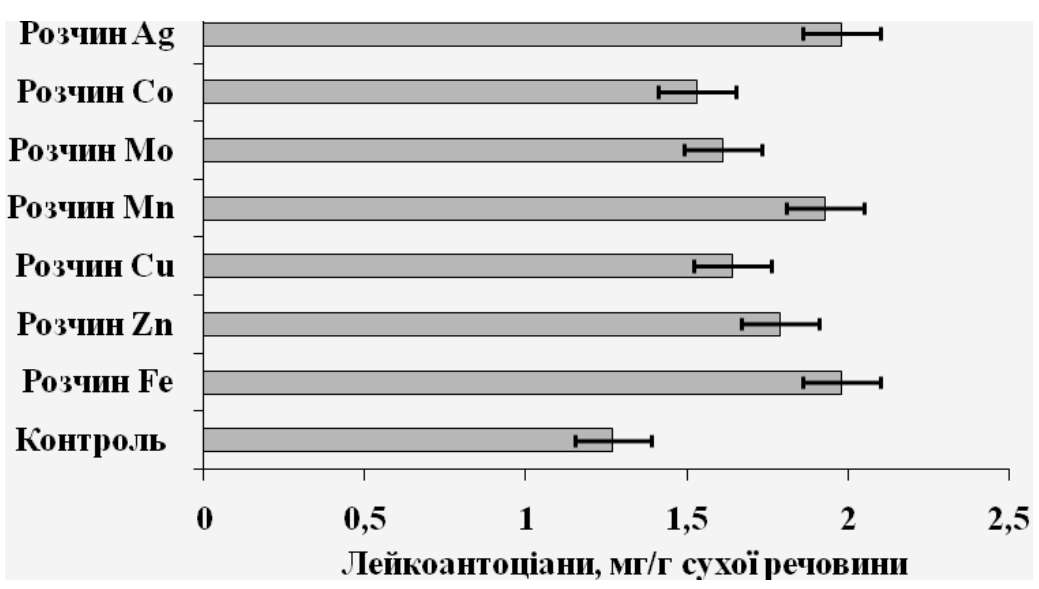

Рис. 4. Вміст лейкоантоціанів у зерні сої за передпосівної обробки нанопрепаратами, у перерахунку на лейкоцианідин 


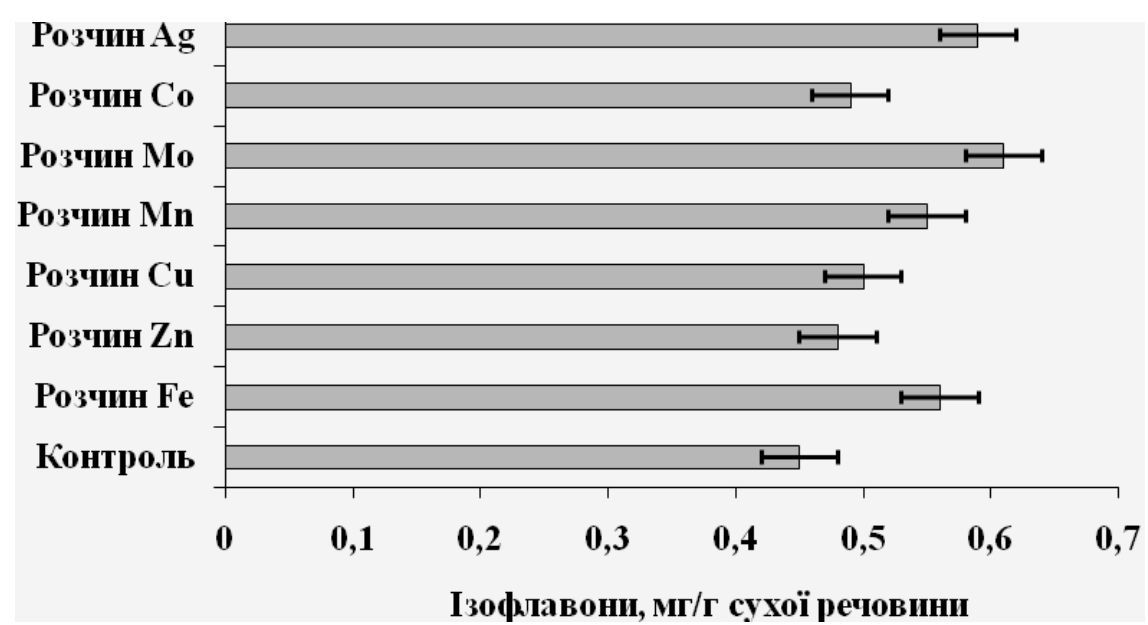

\section{Рис. 5. Вміст ізофлавонів у зерні сої за передпосівної обробки нанопрепаратами, у перерахунку на геністеӥн}

Висновок. Доведено можливість регуляції вмісту фармакологічно цінних речовин у насінні сої елементами мінерального живлення. Біофортифікація наночастинками металів сприяє підвищенню вмісту харчових і фармакологічно цінних сполук фенольної природи в насінні сої. Зокрема, передпосівна обробка неіонними колоїдними розчинами наночасток металів на основі срібла, молібдену, марганцю та заліза сприяла

\section{БІБЛІОГРАФІЯ}

1. Бурлака О. М. Рослинні біотехнології: біофортифікація харчових рослин / О. М. Бурлака, Б. В. Сорочинський // К. : ДІА, 2010. - 88 с.

2. Доспехов Б. А. Методика полевого опыта / Б. А. Доспехов // 5-е изд., перераб. и доп. - М. : Агропромиздат, 1985. - $351 \mathrm{c}$.

3. Aldercreutz $C$. Soybean phytoestrogen intake and cancer risk / C. Aldercreutz // Journal of Nutrition. - 1995. - V. 25. - № 13. - P. 757-770.

4. Anderson J. J. Orally dosed genistein from soy and prevention of cancerous bone loss in two ovarieoctomized rat models / J. J. Anderson, W. W. Ambrose, S. C. Gamer // Journal of Nutrition. 1995. - V. 123. - P. 799.

5. Anthony M. Effects of soy protein and phytoestrogens on cardiovascular risk factors in rhesus monkeys / M. Anthony, T. Clarkson, D. Weddle, M. Wolfe // Journal of Nutrition. - 1995. - V. 25. N 3. - P. 803-804.

6. Cassidy A. Biological effects of a diet of soy protein rich in isoflavones on the menstrual cycle of premenopausal women / Cassidy A., Bingham S., Setchell K. // American Journal of Clinical Nutrition. - 1994. - V. 60. - P. 333-340.

7. Malenčić D. Phenolic Content and Antioxidant зростанню вмісту лейкоантоціанів; вміст ізофлавонів збільшився у середньому на $30 \%$ відносно контролю. Крім того було відмічено достовірне зростання вмісту поліфенолів, що може свідчити про позитивний вплив передпосівної обробки неіонними колоїдними розчинами наночасток металів на синтез й акумуляцію сполук фенольної природи в насінні сої.

Properties of Soybean (Glycine max (L.) Merr.) Seeds / D. Malenčić, M.Popović, J. Miladinović // Molecules, 2007. - 12. - P. 576-581.

8. Hagerman A. Quantification of Tannins in Tree Foliage - aLaboratory Manual / A. Hagerman, I. Harvey-Mueller, H. P. S. Makkar // FAO/IAEA: Vienna, 2000.

9. Kitamura $K$. Low isoflavone content in some early maturing cultivars so-called summer-type soybeans / K. Kitamura, K. Igita, A. Kikuchi, S. Kudou, K. Okubo // Jpn. J. Breed. - 1991. V. 41. - P. 651-654.

10. Liggins J., Bluck L.J.C., Coward W.A., Bingham A. Extraction and quantification of daidzein and genistein in food / J. Liggins, L. J. C. Bluck, W. A. Coward, A. Bingham // Anal. Biochem. - 1998. - V. 264. - P. 1-7.

11. Lori Coward N. Daidzein and their (3glycosiclic conjugates: Antitumor isoflavones in soybean foods from American and Asian diets / N. Lori Coward, C. B. K. D. R. Setchell, S. Genistein Barnes // J. Agric. Food Chem. - 1993. - V. 41. - P. 1961-1967.

12. Marckam K. R. Methods in Plant Biochemistry / K. R. Marckam // Academic Press: London, 1989. 
13. Messina $M$. The role of soybean products in reducing cancer risks / M. Messina, S. Barnes // Journal Of The National Cancer Institute. - 1991. V. 83. - P. 541-546.

14. Messina M., Persky V., Setchell K., Barnes S. Soy intake and cancer risk: A review of the in vitro and in vivo data / M. Messina, V. Persky, K. Setchell, S. Barnes // Nutrition Cancer. - 1994. V. 27. - № 2. - P. 113-131.

15. Miyazawa M. Antimutagenic activity of isoflavones from soybeans seeds (Glycine max Merrill) / M. Miyazawa, K. Sakano, S. Nakamura, H. Kosaka // J. Agric. Food Chem. - 1999. - V. 47. - P. 1346-1349.

16. Pariza M. Soybeans inhibit mammary tumours in models of breast cancer / M. Pariza, H. Aeschbacher, J. Felton, S. Sato // Mutagens and carcinogens in the diet. - New York: Wiley-Liss, 1990. - P. 239-253.

17. Potter S. Soy protein and cardiovascular disease: The impact of bioactive components in soy / S. Potter // Nutrition Reviews. - 1998. - V. 56. № 8. - P. 231-235.

18. Rishi R. K. Phytoestrogens in health and illness / R. K. Rishi // Indian J. Pharmacol. - 2002. V. 34. - P. 311-320.

19. Singleton V. L. Colorimetry of total phenolics with phosphomolybdic-phosphotungstic acid reagents / V. L. Singleton, J. A. Rossi // Am. J. Enol. Vitic. - 1965. - 16. - P. 144-58.
20. Tannin assay Adapted from A. E. Hagerman and L.G. Butler. Protein precipitation method for thequantitative determination of tannins / A. E. Hagerman, L. G. Butler // J. Agric. Food Chem. 1978. - 26. - P. 809-812.

21. Tsukamoto C., Shimada S., Igita K., Kudou S., Kokubun M., Okubo K., Kitamur K. Factors affecting isoflavone content in soybean seeds: Changes in isoflavones, saponins, and composition of fatty acids at different temperatures during seed development / C. Tsukamoto, S. Shimada, K. Igita, S. Kudou, M. Kokubun, K. Okubo, K. Kitamur // J. Agiic. Food Chem. - 1995. - V. 43. - P. 1184-1192.

22. Vishal S. Influence of Metal Nanoparticles on the Soil Microbial Community and Germination of Lettuce Seeds / Vishal Shah, I. Belozerova // Water Air Soil Pollut. - 2009 - 197. - P. 143-148.

23. Wang $C$. Isoflavone content among maturity group 0 to II soybeans / C. Wang, M. Sherrard, S. Pagadola, R. Wixon, R. A. Scott // J. Am. Oil Chem. Soc. - 2000. - V. 77. - P. 483-487.

24. Wei $H$. Antioxidant and antipromotional effects of the soybean isoflavone genistein / H. Wei, R. Bowen, Q. Cai, S. Barnes, Y. Wang // Proceedings of the Society for Experimental Biology and Medicine. - 1995. - V. 208. - P. 124-130.

25. $X u B$. Characterization of phenolic substances and antioxidant properties of food soybeans grown in the North Dakota-Minnesota region / B. Xu, SK. Chang // J Agric Food Chem. - 2008 - 56(19) P. 102-113. 